\title{
STUDY OF THE EFFECT OF OBESITY ON IMMUNE CELLS ACTIVITY AND CARDIOVASCULAR DISEASE RISK IN EL-OUED (ALGERIA) WOMEN
}

\author{
IKRAM ACHCHI ${ }^{1}$, SAMIR DEROUICHE ${ }^{1,2 *}$ \\ ${ }^{1}$ Department of Cellular and Molecular Biology, Faculty of Natural and Life Sciences, El-Oued University, El Oued 39000, El Oued, Algeria. \\ ${ }^{2}$ Laboratory of Biodiversity and Application of Biotechnology in the Agricultural Field, Faculty of Natural Sciences and Life, University of El \\ Oued, El-Oued 39000, Algeria. Email: dersamebio@gmail.com \\ Received: 22 February 2021, Revised and Accepted: 16 March 2021
}

ABSTRACT

Objective: This study was conducted to find out the effect of obesity on immune cells activity and some biochemical markers in women.

Methods: The experimentation is carried out on 30 voluntary individuals were divided into two groups; 15 women with obesity (Body Mass Index $[\mathrm{BMI}]>30)$ were selected, On the other hand, we took 15 witnesses $(\mathrm{BMI}<30)$. All the volunteers were subjected to estimate the lipid profile, biochemical, and hematological parameters.

Results: Results obtained show that there was a significant increase of blood glucose $(\mathrm{p}<0.05)$, triglyceride $(\mathrm{p}<0.05)$ and uric acid $(\mathrm{p}<0.001)$ and no significant change of other biochemical markers in obese people's group when compared to the control subjects. In addition, the hematological results demonstrated that there was a significant decrease $(p<0.05)$ of lymphocytes, hemoglobin, hematocrit, and mean corpuscular volume levels $(p<0.01)$ in women with obesity compared to the controls.

Conclusion: Our study reveals that the obesity may be induce the sever alteration in lipid profile which cause the cardiovascular risk for this population. In addition, the obesity causes a remarkable change in some biochemical markers and blood constituent's anemia or other metabolic disorder in the body.

Keywords: Obesity, Immune cells, Biochemical markers, Women.

(C) 2021 The Authors. Published by Innovare Academic Sciences Pvt Ltd. This is an open access article under the CC BY license (http://creativecommons. org/licenses/by/4.0/) DOI: http://dx.doi.org/10.22159/ijms.2021v9i3.41189. Journal homepage: https://innovareacademics.in/journals/index.php/ijms

\section{INTRODUCTION}

"Globesity" is a word used by the World Health Organization (WHO) to describe the global epidemic of overweight and obesity, this latter considered like one of the most important health problems in the many countries [1]. Obesity is the convergence of environmental, genetic, and human behavior factors, and it may also be the result of an energy imbalance in the body [2]. Where the degrees of obesity appear on the person if body mass index (BMI) $>30$, this indicator is calculated by dividing the weight in kilograms by the square of the height in meters [3]. Obesity and overweight have been linked to various health disorders, including breast cancer [4]. Furthermore, the latest studies related to Coronavirus disease-19 have shown that diabetes is a major risk factor for developing disease symptoms in this group [5]. Hebce, obesity has a share in the evolution of the virus and also considered like cause of cancer, this latter is the second cause of death in the world after cardiovascular disease [6] and because it occurs with depression frequently [7]. It is also considered alongside metabolic diseases, diabetes, and all conditions that are characterized by abdominal fat, are well-recognized risk factors for sexual dysfunction in both sexes [8].

The number of people in the world who are obese or overweight is estimated at more than 2.1 billion, which is considered one of the most important causes of death in the world, with an annual rate of more than 3.4 million deaths [9]. We can take some possible controls for obesity such as: Physical activity, A reduction in food intake alone is seldom effective in reduce of weight, and unless accompanied by some daily physical activities to increase energy expenditure [10]. Furthermore, the role of aqueous plant extract of $P$. olercea was reached 3 years before the current time, in reducing the levels of fat and sugar in the blood that is why it plays an important role against the development of obesity [11]. The many effects of obesity on human health prompted us to complete a study that aimed at evaluate the effect of obesity on immune cells activity and some biochemical parameter in women of ElOued region.

\section{METHODS}

\section{Ethical clearance}

Ethical approval was requested and approved by the Ethics Committee of the Department of Cellular and Molecular Biology, Faculty of Natural Sciences and Life, University of El Oued.

\section{Study subject}

The study was conducted on 30 volunteers, whose ages ranged from 26 to 63 years. It is divided into two groups that correspond in the age, 15 of them are obese women (BMI $>30$ ) their mean age is $44.07 \pm 12.52$ years old. On the other hand, there are 15 other women who are not obese $(\mathrm{BMI}<30$ their mean age is $44.00 \pm 12.03$ years old. All the volunteers (control and patients) in this study live in the El Oued area located in the southeast of Algeria.

\section{Inclusion and exclusion criteria}

About inclusion criteria for obesity, we chose women who were apparently obese and then confirmed this by calculating the BMI. Women who have a BMI $>30$ were organized for the study.

This means that we selected women with a BMI of $<30$ and outwardly healthy as controls, between 16.66 and 27.18. In our study, we excluded pregnant women or women with chronic diseases.

\section{Laboratory investigations}

Blood samples were collected and placed into containing tubes. Blood was transferred into EDTA tubes for hematological markers and the 
serum was obtained after centrifugation. Using a machine named NE 200 and its Model Nuve at 3000 tour for 5 min, Hematological analysis (FNS) is performed by the hematology

Auto analyzer (name: BC - 2800, model: Mindray). As for the rest of the analyses biochemical, it is usually performed using Spinreact reactive little is used Biomaghreb reactive and appareile of spectrophotomètre (name: BA- 88A, model: Mindray)

\section{Statistical analysis}

This study was prepared using MiniTab program. And express the results an average Mean \pm ES (standard deviation). We also GOT $p$ value after comparing the average values of the patients with the average of the control values whereas the difference gets bigger whenever $\mathrm{p}<0.05$

\section{RESULTS}

\section{Descriptive of study population}

The study was conducted in state of El-Oued - the Public Institution for Slave Health - Saad Al-Amamrah in Dabila - multi service in Hassani Abdul Karim, at the level of the medical laboratory. The number of women in our study reached 15 sick women suffering from obesity and 15 other women who were not obese. The results obtained show that there is no significant difference concerning mean age, and the length. In contrast to the weight and the BMI, which appear with a very wide difference (Table 1).

\section{Biochemical markers}

The results obtained showed great agreement on the level of bilirubin total in obese and control women, followed by levels of GOT Least compatible then levels of GPT, calcium, bilirubin direct. Then the cholesterol results $(p=0.056)$ show very little convergence between the two groups, because it takes higher levels in patients than for the control women and the levels of blood sugar (0.020) and triglycerides (0.014) differ between the two groups. And uric acid values are completely different (Table 2).

\section{Hematological markers}

Our results showed consistent values for total white blood cells, followed by levels of monocytes and granulocytes least compatible in obese and control women. Then, the total red blood cells results $(p=0.189)$, while the values of lymphocytes $(p=0.035)$. It is higher levels when obese women. Hemoglobin ( $p=0.043)$, mean corpuscular volume

Table 1: Description of study population

\begin{tabular}{lccc}
\hline Parameters & $\begin{array}{c}\text { Control } \\
\text { group }(\mathbf{n = 1 5})\end{array}$ & $\begin{array}{c}\text { Patient } \\
\text { group }(\mathbf{n = 1 5})\end{array}$ & p-value \\
\hline The Age & $44.00 \pm 12.03$ & $44.07 \pm 12.52$ & 0.984 \\
Body weight & $70.67 \pm 8.81$ & $112.13 \pm 19.92$ & 0.000 \\
Length & $1.5800 \pm 0.0672$ & $1.5873 \pm 0.0644 \&$ & 0.666 \\
Body mass index & $22.428 \pm 3.166$ & $35.27 \pm 6.65$ & 0.000 \\
\hline
\end{tabular}

Table 2: Levels of biochemical analysis in control and obese patients

\begin{tabular}{|c|c|c|c|}
\hline Parameters & $\begin{array}{c}\text { Control } \\
\text { group }(n=15)\end{array}$ & $\begin{array}{c}\text { Patient } \\
\text { group }(n=15)\end{array}$ & p-value \\
\hline Blood sugar (g/l) & $0.8145 \pm 0.0520$ & $1.182 \pm 0.541$ & 0.020 \\
\hline $\begin{array}{l}\text { Serum Total } \\
\text { cholesterol (g/l) }\end{array}$ & $1.6100 \pm 0.1947$ & $1.7807 \pm 0.3048$ & 0.056 \\
\hline $\begin{array}{l}\text { Serum } \\
\text { triglycerides }(\mathrm{g} / \mathrm{l})\end{array}$ & $0.9169 \pm 0.3187$ & $1.360 \pm 0.523$ & 0.014 \\
\hline Serum Uric acid (mg/l) & $26.04 \pm 5.74$ & $43.11 \pm 11.49$ & 0.000 \\
\hline Serum GOT (UI/l) & $32.15 \pm 6.85$ & $30.29 \pm 6.90$ & 0.330 \\
\hline Serum GPT (UI/l) & $31.70 \pm 9.72$ & $26.87 \pm 11.22$ & 0.118 \\
\hline Serum calcium (mg/l) & $83.13 \pm 4.24$ & $79.47 \pm 8.57$ & 0.120 \\
\hline Serum Bd (mg/l) & $0.8493 \pm 0.1092$ & $0.7847 \pm 0.1718$ & 0.167 \\
\hline Serum Bt (mg/l) & $5.149 \pm 1.059$ & $5.163 \pm 1.036$ & 0.958 \\
\hline
\end{tabular}

(MCV) (0.037), and hematocrit (0.049) are shown clear difference between obese and control women, where it appears at lower levels in obese women. And the most different values are values of platelets $(\mathrm{p}=0.001)$, it is high in patient women (Table 3 )

\section{DISCUSSION}

Obesity has emerged as a complex metabolic disease characterized by abnormal or excessive fat $\left(\mathrm{BMI} \geq 30 \mathrm{~kg} / \mathrm{m}^{2}\right)$ that may adversely affect health [12]. This explains the high level of triglycerides obtained in the obese women in our study. Cholesterol levels are also high, but significant. A large tissue mass needs more energy which was produced in addition to secondary products such as free-oxygen radicals, central obesity (excessive fat deposition intra-abdominally and in the abdominal wall subcutaneous tissue) also causes systemic release of adipose-derived inflammatory cytokines, which, in turn, cause oxidative stress (OS) and insulin resistance (IR). IR leads to higher circulating glucose, which itself increases OS, thus a vicious cycle is set up which can result in type 2 diabetes [13-15]. This translates into higher blood glucose values for obese women, which increases the risk of developing type 2 diabetes. On the other hand, the results showed an increase in the level of uric acid in obese women, which may explain the effect of this criterion on IR to reduce the urine excretion of uric acid. King et al. [16], clinical studies, too, indicate that the sufferer from gout tends to be overweight [17]. In addition, the inverse relationship between obesity resulting from imbalance in the irregular diet and immunity makes obese people more sensitive to infections, which makes them less responsive to vaccines [18]. There is also a close relationship between adipose tissue and chronic inflammatory processes that may affect infection resistance. White adipose tissue (WAT) is usually found at higher levels in obese people. Several studies show that WAT has many functions, including regulating inflammatory processes. When the body has an excess of WAT, chronic inflammation makes it difficult for the body to fight infection [19]. Adipocytes and osteoblasts are derived from a common multipotential mesenchymal stem cell [20]. White blood cell count was elevated in obesity [21], studies have found that, there is some sort of association between the increased number of immune cells and obesity as a result of a chronic inflammatory condition which is created by an increase in the production of cytokines by adipose tissue [22]. However, in our study, the white blood cell values did not show a significant difference. However, from the average values, we can notice their slight increase in the obese compared to the healthy. With the exception of monocyte, it showed a significant difference and was low in obese people. The induction of cytokines such as Tumor necrosis factor- $\alpha$ and interleukin (IL-6) is involved in transcriptional reprogramming induced by $\mathrm{CIH}$ [23]. On the one hand, it has been shown that the administration of IL- 6 in the human body increased the number of circulating platelets, and on the other hand, obesity has been shown not to be associated with increased platelet activation [24]. And because obesity means an increase in fat tissue, this means an increase in the level of platelets. Study of Sen et al., (2009) conducted that increasing tertiles of abdominal height were significantly associated

Table 3: Hematological parameters levels in control and obese patients

\begin{tabular}{lccc}
\hline Parameters & $\begin{array}{c}\text { Control } \\
\text { group }(\mathbf{n = 1 5})\end{array}$ & $\begin{array}{c}\text { Patients } \\
\text { group }(\mathbf{n = 1 5})\end{array}$ & p-value \\
\hline Total WBC count $\left(\times 10^{9} / \mathrm{L}\right)$ & $7.37 \pm 1.27$ & $7.56 \pm 2.39$ & 0.767 \\
Lymphocytes $\left(\times 10^{9} / \mathrm{L}\right)$ & $2.89 \pm 0.88$ & $2.493 \pm 0.665$ & 0.035 \\
Monocytes $\left(\times 10^{9} / \mathrm{L}\right)$ & $0.09 \pm 0.49$ & $0.46 \pm 0.10$ & 0.242 \\
Granulocytes $\left(\times 10^{9} / \mathrm{L}\right)$ & $3.98 \pm 0.83$ & $4.60 \pm 2.02$ & 0.256 \\
Hb $(\mathrm{g} / \mathrm{dL})$ & $10.39 \pm 0.73$ & $9.60 \pm 1.38$ & 0.043 \\
Total RBC count $\left(\times 10^{12} / \mathrm{L}\right)$ & $4.02 \pm 0.31$ & $3.86 \pm 0.44$ & 0.189 \\
Hematocrit $\%$ & $34.16 \pm 2.29$ & $31.65 \pm 4.52$ & 0.049 \\
MCV & $85.22 \pm 3.71$ & $81.95 \pm 5.48$ & 0.037 \\
platelets $\left(\times 10^{9} / \mathrm{L}\right)$ & $229.9 \pm 69.5$ & $295 \pm 63$ & 0.001 \\
\hline
\end{tabular}

Hb: Hemoglobin, WBC: White blood cells, RBC: Red blood cells, MCV: Mean corpuscular volume 
with increasing levels of mean platelet count in women [25]. About $50 \%$ of total body mass is fat tissue which may stimulate immune cells to the innate and adaptive response [26]. When the red blood cell count or hemoglobin concentration decreases, anemia results, which affects the amount of oxygen in the cells, which affects their energy levels [27]. This means that obese women suffer from anemia compared to healthy women, $\mathrm{p}$ value of hemoglobin levels is $0.043<0.05$. This decrease is also accompanied by a decrease in the level of values: Hematocrit, MCV, although red blood cell values are close between the two groups.

\section{CONCLUSION}

Based on the results obtained during our study and obtained in the scientific tribal studies, based on the results we obtained during our study and that we obtained in the scientific tribal studies. We can say that obesity causes many diseases for women. It is also responsible for response immune changes and disturbances of some biochemical parameters which can lead to several metabolic diseases.

\section{ACKNOWLEDGMENTS}

The author thanks the staff of laboratory, Debila Hospital and multiservice of Hassani Abdelkarim hospital for providing research facilities to carry out present work. This work was supported by the research project D01N01UN390120190001 funded by the ministry of higher education, Algeria and by Directorate general for Scientific Research and Technological Development.

\section{AUTHORS' CONTRIBUTION}

All the authors have contributed equally in the research.

\section{CONFLICTS OF INTEREST}

There are no conflicts of interest in my study.

\section{SOURCE OF FUNDING}

None.

\section{REFERENCES}

1. Filomena M. Current concept of obesity. J Sports Sci 2016;9:1-16.

2. Omer T. The causes of obesity: An in-depth review. Adv Obes Weight Manag Control 2020;10:90-4.

3. Nuttall FQ. Body mass index. Nutr Today 2015;50:117-28.

4. Derouiche S, Atoussi N, Guediri S. Assessment of hematological parameters, enzymes activities, and oxidative stress markers in salivary and blood of Algerian breast cancer patients receiving chemotherapy. J Biochem Technol 2019;10:50-8.

5. Derouiche S, Taissir C, Abdelmalek D, Achi I. Effect of COVID-19 infection on the immune system and risk of developing diabetes complications: A review. J Pharm Care 2020;8:133-9.

6. Derouiche S, Djouadi A, Belimi N, Louetri K, Hachefa S. Blood glucose, some electrolytes levels and stress oxidative status of female hyperthyroid patients under treatment. J Adv Res Biochem Pharm 2018;3:1-6.

7. Nigatu YT, Reijneveld SA, De Jonge P, Van Rossum E, Bültmann U. The combined effects of obesity, abdominal obesity and major depression/ anxiety on health-related quality of life: The LifeLines Cohort Study. PLoS One 2016;11:e0148871.

8. Maiorino MI, Bellastella G, Giugliano D, Esposito K. From inflammation to sexual dysfunctions: A journey through diabetes, obesity, and metabolic syndrome. J Endocrinol Invest 2018;41:1249-58.

9. Ng M, Fleming T, Robinson M, Thomson B, Graetz N, Margono C, et al. Global, regional, and national prevalence of overweight and obesity in children and adults during 1980-2013: A systematic analysis for the Global Burden of Disease Study 2013. Lancet 2014;384:766-81.

10. Samuel H. The tale of obesity: Challenges and solutions. Best Pract Res Clin Gastroenterol 2005;18:1009-29.

11. Samir D, Kaouther A, Manal D. Polysaccharides and ascorbic acid content and the effect of aqueous extract of portulaca oleracea in highfat diet-induced obesity, dyslipidemia and liver damage in albino wistar rats. Algerian J Arid Environ 2017;7:16-26.

12. De Lorenzo A, Gratteri S, Gualtieri P, Cammarano A, Bertucci P, Di Renzo L. Why primary obesity is a disease? J Transl Med 2019;17:169.

13. Fernández-Sánchez A, Madrigal-Santillán E, Bautista M, EsquivelSoto J, Morales-González A, Esquivel-Chirino C, et al. Inflammation, oxidative stress, and obesity. Int J Mol Sci 2011;12:3117-32.

14. Marseglia L, Manti S, D’Angelo G, Nicotera A, Parisi E, Di Rosa G, et al. Oxidative stress in obesity: A critical component in human diseases. Int J Mol Sci 2014;16:378-400.

15. Jenna LT, David JH, Gregore IM, Tom GB, Nathan AJ, Michael DL, et al. Effect of high-intensity interval training on visceral and liver fat in cardiac rehabilitation: A randomized controlled trial. Obesity 2020;28:1245-53.

16. King C, Lanaspa MA, Jensen T, Tolan DR, Sánchez-Lozada LG, Johnson RJ. Uric acid as a cause of the metabolic syndrome. Contrib Nephrol 2018;192:88-102.

17. Nielsen SM, Bartels EM, Henriksen M, Wæhrens EE, Gudbergsen H, Bliddal $\mathrm{H}$, et al. Weight loss for overweight and obese individuals with gout: A systematic review of longitudinal studies. Ann Rheum Dis 2017;76:1870-82.

18. Magrone T, Jirillo E. Childhood obesity: Immune response and nutritional approaches. Front Immunol 2015;6:76.

19. Pahwa R, Goyal A, Bansal P, Jialal I. Chronic Inflammation. Treasure Island, FL: StatPearls Publishing; 2020.

20. Aicha Z, El-Houda HN, Samir D. Analysis of osteoporosis risk factors in menopausal women's of Algeria population. Asian J Res Pharm Sci 2020;10:79-84.

21. Dixon JB, O'Brien PE. Obesity and the white blood cell count: Changes with sustained weight loss. Obes Surg 2006;16:251-7.

22. Ellulu MS, Patimah I, Khaza'ai H, Rahmat A, Abed Y. Obesity and inflammation: The linking mechanism and the complications. Arch Med Sci 2017;13:851-63.

23. Derouiche S. Oxidative stress associated with SARS-Cov-2 (COVID-19) increases the severity of the lung disease - A systematic review. J Infect Dis Epidemiol 2020;6:121.

24. Bastard JP, Maachi M, Van Nhieu JT, Jardel C, Bruckert E, Grimaldi A, et al. Adipose tissue IL-6 content correlates with resistance to insulin activation of glucose uptake both in vivo and in vitro. J Clin Endocrinol Metab 2002;87:2084-9.

25. Sen N, Basar N, Maden O, Ozcan F, Ozlu MF, Gungor O, et al. Increased mean platelet volume in patients with slow coronary flow. Platelets 2009;20:23-8.

26. Ferrante AW. The immune cells in adipose tissue. Diabetes Obes Metab 2013;15 Suppl 3(03):34-8.

27. Johnson-Wimbley TD, Graham DY. Diagnosis and management of iron deficiency anemia in the $21^{\text {st }}$ century. Therap Adv Gastroenterol 2011;4:177-84. 